\title{
ВПРОВАДЖЕННЯ НОВІТНІХ ТЕХНОЛОГІЙ У ПРОЦЕС ВИКЛАДАННЯ УКРАЇНСЬКОЇ МОВИ ЯК ІНОЗЕМНОЇ
}

\author{
Фоменко Т. М. \\ кандидат педагогічних наук, доиент, \\ доиент кафедри іноземних мов \\ Сумський наџіональний аграрний університет \\ вул. Г. Кондратьєва, 160, Суми, Украӥна \\ orcid.org/0000-0002-3048-7097 \\ taniafomenko75@gmail.com
}

\begin{abstract}
Ключові слова: новітні технологї навчання, інтерактивні методи, групова робота, украӥнська мова як іноземна, іноземні студенти.
\end{abstract}

У статті охарактеризовано особливості інноваційних технологій, доцільність їх упровадження у навчальний процес викладання української мови як іноземної. Зазначено, що інтерактивні технології забезпечують максимальну активізацію комунікативної діяльності на занятті з української мови як іноземної шляхом активного використання групових форм міжособистісної взаємодії. 3'ясовано, що підгрунтям інтерактивних технологій $є$ взаємодія, співробітництво, спільний пошук. Засвоєння інформації буде більш ефективним, якщо воно здійснюється у співробітництві, коли кожний студент стає активним учасником освітнього процесу. Розглянуто можливості та практичне значення використання роботи в малих групах. Підкреслюється, що використання роботи в малих групах $\epsilon$ доцільним для кращого засвоєння матеріалу, для об'єднання інтернаціональної групи студентів. Наголошується, що перевагами спільної навчальної діяльності є те, що робота у малих групах: 1) породжує інтерактивне мовлення; 2) створює емоційно позитивний клімат, який забезпечує почуття безпеки; 3) сприяє підвищенню відповідальності та автономності студента; 4) є кроком до індивідуалізації навчання. Навчання у співробітництві, робота в команді, колективні способи навчальної роботи забезпечують вимушену пізнавальну активність і високий рівень комунікації студентів. Саме ця стратегія сприяє формуванню в іноземних студентів комунікативного досвіду, досвіду співпраці, узгодження інтересів і позицій, спільного прийняття рішень тощо. Щодо труднощів, з якими доводиться стикатися іноземним студентам під час групової роботи, виокремлюють брак словникового запасу і вміння граматично коректно оформляти свої думки. У результаті дослідження встановлено, що застосування групових форм роботи сприяє як оволодінню українською мовою, підвищенню пізнавального рівня засвоєння і закріплення знань, так і виробленню соціальних навичок комунікації та взаємодії іноземних студентів (вміння встановлювати контакти, працювати в команді, аналізувати, критично мислити, відстоювати свій погляд тощо), згуртуванню колективу. Предметом подальших наукових досліджень може бути визначення інших інтерактивних методів, які можуть бути використані в навчальному процесі викладання української мови як іноземної. 


\title{
IMPLEMENTATION OF NEW TECHNOLOGIES INTO THE PROCESS OF TEACHING UKRAINIAN AS A FOREIGN LANGUAGE
}

\author{
Fomenko T. M. \\ Candidate of Pedagogical Sciences, Associate Professor, \\ Associate Professor at the Foreign Languages Department \\ Sumy National Agrarian University \\ H. Kondratiev str., 160, Sumy, Ukraine \\ orcid.org/0000-0002-3048-7097 \\ taniafomenko75@gmail.com
}

Key words: new teaching technologies, interactive methods, group work, Ukrainian as a foreign language, foreign students.

\begin{abstract}
The article deals with the analysis of the peculiarities of innovative technologies, determination of the feasibility of their implementation into the educational process of teaching Ukrainian as a foreign language. It is noted that interactive technologies provide maximum activation of communicative activity at Ukrainian language classes through active use of group forms of interpersonal interaction. It was found out that the basis of interactive technologies is interaction, cooperation, and joint search. Assimilation of information will be more effective if it is carried out in cooperation, when each student becomes an active participant of the educational process. The possibilities and practical significance of using work in small groups are considered. It is underlined that applying work in small groups is expedient for the best mastering of material, for uniting an international group of students. It is emphasized that the advantages of joint educational activities are that work in small groups: 1) generates interactive speech;2) creates an emotionally positive climate that provides a sense of security; 3 ) promotes the responsibility and autonomy of the student; 4 ) is a step towards individualization of learning. Collaborative learning, teamwork, collective learning methods provide forced cognitive activity and a high level of student communication. This strategy promotes the formation of foreign students' communicative experience, the experience of cooperation, coordination of interests and positions, joint decision-making, etc. Regarding the difficulties that foreign students have to face during group work, there is a lack of vocabulary and the ability to correct grammatically their thoughts. As a research result it is underlined that the use of group forms of work helps to master the Ukrainian language, increase the cognitive level of learning and consolidation of knowledge, and develop social skills of communication and interaction of foreign students (ability to establish contacts, work in a team, analyze, think critically, defend their view, etc.), team cohesion. The subject to further scientific research will focus on the determination of other interactive methods which can be used in the educational process of teaching Ukrainian as a foreign language.
\end{abstract}

Постановка проблеми. Сучасний етап розвитку вищої освіти в Україні характеризуються іiі інтеграцією у світове співтовариство, розширенням міжнародних контактів і залученням іноземних громадян до навчання в українських закладах вищої освіти. Зважаючи на те, що українська мова використовується іноземними студентами як для здобуття вищої освіти, так і для спілкування в іншомовному середовищі, це зумовлює необхідність модернізації процесу мовної підготовки іноземних студентів. Перед викладачами постає проблема пошуку шляхів підвищення пізнаваль- ного інтересу іноземних студентів до вивчення української мови, закріплення їхньої позитивної мотивації до навчання. Однією із можливостей вирішення цієї проблеми $є$ впровадження новітніх технологій у навчальний процес.

Проблему якості навчання і застосування інноваційних технологій у своїх роботах розглядає багато вчених, зокрема: І. Дичківська, М. Кадемія, С. Сисоєва, Л. Пироженко, Є. Полат, О. Пометун та ін. Методологію викладання української мови як іноземної досліджували такі науковці, як Д. Мазурик, 3. Мацюк, О. Тростинська, Г. Шелест 
та ін. Питанням інноваційного навчання української мови як іноземної у закладах вищої освіти займалися Л. Назаревич (методи ейдетики), О. Новіцька (мозковий штурм, метод асоціацій), А. Новосьолова (мультимедійні презентаціі), Л. Роман (інформаційні технології), М. Світлик (рольові ігри) та ін.

Проте залишається актуальним питання відбору тих методів і форм роботи, які надають можливість викладачам української мови як іноземної підвищити ефективність навчального процесу, максимально активізувати комунікативну діяльність студентів.

Мета статті - охарактеризувати особливості інноваційних технологій, доцільність їх упровадження у процес викладання української мови як іноземної.

Виклад основного матеріалу дослідження. Серед інноваційних технологій навчання великого значення нині набувають інтерактивні технології, які забезпечують максимальну активізацію комунікативної діяльності на занятті з української мови як іноземної шляхом активного використання групових форм міжособистісної взаємодії. Саме використання інтерактивних технологій на заняттях української мови, на думку дослідників, може заповнити брак мовної практики у реальному середовищі [3].

Поняття «інтерактивний» у перекладі з англійської мови означає взаємодіючий, який впливає один на одного [1]. У педагогіці під інтеракцією розуміється спосіб пізнання, що здійснюється у формі спільної діяльності, коли всі учасники освітнього процесу взаємодіють один $з$ одним, обмінюються інформацією, спільно вирішують проблеми, моделюють ситуації.

Така форма організації навчальної діяльності створює найоптимальніші умови для постійної мовленнєвої взаємодії всіх студентів, що особливо важливо у вивченні української мови для досягнення комунікативної мети навчання. Особливо актуально це для інтернаціональної групи, де необхідно створити комфортні умови навчання студентам з різних країн, 3 різними культурами, традиціями та релігійними переконаннями.

У процесі викладання української мови як іноземної застосовуються різні організаційні форми роботи: фронтальна, індивідуальна, парна і групова. Однак слід зазначити, що найчастіше використовуються фронтальна, робота в парах та індивідуальна робота. Зрідка застосовується робота в малих групах. Причиною цього може бути значне витрачання часу й зусиль викладача на організацію групової роботи, а також необхідність підготовки студентів до проведення такої роботи. Значно змінюється й функція викладача: із «транслятора знань» він перетворюється на помічника, консультанта.
На наш погляд, для кращого засвоєння матеріалу, а також для об'єднання групи доцільним $\epsilon$ використання роботи в малих групах. Зазначена форма роботи має велике значення як для оволодіння українською мовою, так і для вироблення соціальних навичок комунікації та взаємодії іноземних студентів. Завдяки використанню групових форм роботи підвищується не лише пізнавальний рівень засвоєння і закріплення знань, але й відбувається згуртування колективу, оскільки в групах збираються студенти з різних країн.

Сутність інтерактивного навчання полягає в тому, що навчальний процес організований таким чином, що практично всі студенти залучаються до процесу пізнання, мають можливість розуміти і виражати свою точку зору. При цьому завдання студентів не зводиться до простого отримання знань і поповнення свого словникового запасу, а спрямоване на вироблення вміння спілкуватися українською мовою, взаємодіяти і співпрацювати 3 іншими студентами та працювати на загальний результат. Спільна діяльність у процесі пізнання, засвоєння навчального матеріалу означає, що кожен вносить індивідуальний внесок, йде обмін знаннями, ідеями, способами діяльності.

Перевагами спільної навчальної діяльності $\epsilon$ те, що робота у малих групах: 1) породжує інтерактивне мовлення; 2) створює емоційно позитивний клімат, який забезпечує почуття безпеки; 3) сприяє підвищенню відповідальності та автономності студента; 4) $є$ кроком до індивідуалізації навчання [6, с. 178-179].

Так, підгрунтям інтерактивних технологій $є$ взаємодія, співробітництво, спільний пошук. Завдяки таким методам відбувається ефективне засвоєння навчальної інформації у співпраці з іншими студентами, оскільки ці методи належать до колективних форм навчання. Засвоєння інформації буде більш ефективним, якщо воно здійснюється у співробітництві, коли кожний студент стає активним учасником освітнього процесу. Інноваційні методи навчання спонукають студентів до міжособистісної взаємодії під час навчання, привчають працювати в команді, встановлюють емоційні контакти [2].

Застосування інтерактивних методів на заняттях української мови спрямоване насамперед на розвиток комунікативної компетенції іноземних студентів. Навчання у співробітництві, робота в команді, колективні способи навчальної роботи забезпечують вимушену пізнавальну активність і високий рівень комунікації студентів. Саме ця стратегія сприяє формуванню в іноземних студентів комунікативного досвіду, досвіду співпраці, узгодження інтересів і позицій, спільного прийняття рішень тощо. Таким чином, інтерактивні технології відіграють соціально важливу роль, оскільки є способом впровадження ідей співробітництва в педагогічний процес. 
Під час виконання групового завдання студенти, маючи різні стилі навчання, працюють задля спільної мети. Наявність різних стилів навчання у групі має низку переваг, наприклад розуміння учасниками групи різноманітних підходів і того, як вони можуть допомогти їм досягти спільної мети [7]. Виконуючи групове робоче завдання, студенти використовують стратегії, які допомагають їм успішно виконати завдання.

Основними методами інтерактивних технологій $\epsilon$ діалог (полілог), тобто багатостороння комунікація. Організація діалогічного спілкування зумовлює взаємодію, спільне вирішення завдань. У процесі багатосторонньої комунікації студенти мають можливість ділитися своїми думками, враженнями в межах певної теми, розповісти про власні висновки й вислухати думки інших учасників навчального процесу [5].

Під час роботи в малих групах у студентів виробляється також критичне мислення, зокрема вміння розуміти та застосовувати іншомовний матеріал, порівнювати, аналізувати й оцінювати, і в кінцевому підсумку створювати свій груповий «продукт» у вигляді презентації на задану тему.

Робота в малих групах дозволяє застосувати диференційований підхід, оскільки слабкі студенти виконують більш легкі і посильні завдання, сильні беруть на себе більш складні завдання. Проте недоліком використання групової форми роботи $\epsilon$ відсутність можливості оперативно виправити помилки студентів. Щодо труднощів, 3 якими доводиться стикатися, студенти називають брак словникового запасу і вміння граматично коректно оформляти свої думки. Не всі студенти активно беруть участь, деякі виконують лише малу частину роботи, покладаючись на більш сильних студентів.
Успіх колективної роботи залежить від психологічної готовності студентів до групової роботи; від їхнього бажання спільно працювати; від особистісних і професійних якостей викладача, його вміння раціонально організувати групову діяльність [4]. У процесі групової роботи студенти встановлюють контакти один з одним, обговорюють завдання і проблеми; вчаться вислуховувати один одного, висловлюють свої думки, бачать різні підходи до вирішення проблеми, розширюють свій кругозір, відстоюють свою точку зору і бачать, як корисні спільні обговорення. Все це розвиває соціальні компетенції студентів, вміння враховувати думку інших студентів і приймати спільне рішення, яке найбільш успішно дозволить вирішити поставлене завдання. Така робота дозволяє розкритися кожному студенту.

Висновки. Таким чином, одним із важливих завдань на сучасному етапі модернізації вищої освіти постало забезпечення якості підготовки іноземних студентів. Виконання зазначеного завдання можливе за умови впровадження інноваційних технологій, зокрема інтерактивних методів навчання. Так, використання таких інтерактивних методів, як робота в малих групах сприяє активізації пізнавальної діяльності студентів; підвищує їхню мотивацію до іншомовної діяльності; сприяє розвитку навичок міжособистісного спілкування; удосконалює соціально значущі якості іноземних студентів (вміння встановлювати контакти, працювати в команді, аналізувати, критично мислити, відстоювати свій погляд тощо).

Перспективами подальших наукових розвідок у цьому напрямі може бути визначення інших інтерактивних методів, які використовуються в процесі викладання української мови як іноземної.

\section{ЛIТЕРАТУРА}

1. Бусел В.Т. Англо-український словник. Українсько-англійський словник. Київ : Перун, 2010. 1568 с.

2. Новіцька О.І. Реалізація інноваційних методів навчання на практичних заняттях з української мови як іноземної. Педагогічні науки. Зб. наук. пращь. Вип. LXXIV. T. 3. 2016. C. 77-81.

3. Новосьолова А.К. Формування комунікативої компетенції із залученням інноваційних технологій у процес навчання української мови як іноземної. Сучасний рух науки : тези доп. VII міжнар. наук.-практ. Інтернет-конф. (м. Дніпро, 6-7 черв. 2019 р.). С. 1256-1259.

4. Павлова Е.А. Особенности организации групповой формы работы на уроке иностранного языка. Иностранные языки в школе, 2011. № 9. С. 23-26.

5. Пометун О.І., Пироженко Л.В. Сучасний урок. Інтерактивні технології навчання : науково-методичний посібник. Київ : Вид-во А.С.К., 2004. 192 с.

6. Brown H.D. Teaching by Principles: An Interactive Approach to Language Pedagogy. 2-nd edition. Pearson Education, Inc. 2000. Pp. 176-191.

7. Parnrod U., Darasawang P. Group-work and learning strategies by EFL students with different cognitive styles: Closing gaps for implementing cooperative learning in language classroom. Journal of Institutional Research South East Asia, 2018. No. 16(1). Pp. 71-94. 


\section{REFERENCES}

1. Busel, V.T. (2010). Anhlo-ukrainskyi slovnyk. Ukrainsko-anhliiskyi slovnyk. [English-Ukrainian dictionary. Ukrainian-English dictionary]. Kyiv: Perun, 1568 p. [in Ukrainian].

2. Novitska, O.I. (2016). Realizatsiia innovatsiinykh metodiv navchannia na praktychnykh zaniattiakh z ukrainskoi movy yak inozemnoi. Pedahohichni nauky. Zbirnyk naukovykh prats [Implementation of innovative teaching methods in practical classes on the Ukrainian language as a foreign language. Pedagogical sciences. Collection of scientific works]. Issue LXXIV. Vol. 3. 2016. P. 77-81 [in Ukrainian].

3. Novosiolova, A.K. (2019). Formuvannia komunikatyvoi kompetentsii iz zaluchenniam innovatsiinykh tekhnolohii u protses navchannia ukrainskoi movy yak inozemnoi. Suchasnyi rukh nauky: tezy dopovidi VII mizhnarodnoi naukovo-praktychnoi Internet-konferentsii (m. Dnipro, 6-7 chervnia 2019 r.) [Formation of communicative competence through applying innovative technologies in the process of learning Ukrainian as a foreign language] [in Ukrainian].

4. Pavlova, E.A. (2011). Osobennosti organizatsii gruppovoy formyi rabotyi na uroke inostrannogo yazyika [Features of the organization of the group form of work in a foreign language lesson]. Foreign languages at school. No. 9. P. 23-26 [in Russian].

5. Pometun, O.I., Pyrozhenko, L.V. (2004). Suchasnyi urok. Interaktyvni tekhnolohii navchannia: naukovometodychnyi posibnyk [Contemporary lesson. Interactive learning technologies: a methodological manual]. Kyiv: Publishing house A.S.K. 192 p. [in Ukrainian].

6. Brown, H.D. (2000). Teaching by Principles: An Interactive Approach to Language Pedagogy. 2-nd edition. Pearson Education, Inc. 176-191.

7. Parnrod, U., Darasawang, P. (2018). Group-work and learning strategies by EFL students with different cognitive styles: Closing gaps for implementing cooperative learning in language classroom. Journal of Institutional Research South East Asia, 16 (1), 71-94. 